\title{
Use of high temperature catalytic oxidation (HTCO) to measure carbon content of microorganisms
}

\author{
Sílvia P. Pelegrí*, John Dolan, Fereidoun Rassoulzadegan \\ Marine Microbial Ecology, Laboratoire d'Océanographie Biologique et d'Ecologie du Plancton Marin, CNRS-ESA 7076, \\ Station Zoologique B.P. 28, F-06234 Villefranche-sur-mer, France
}

\begin{abstract}
High temperature catalytic oxidation (HTCO) was used for the first time to determine carbon content of heterotrophic protists (the helioflagellate Pteridomonas danica, the dinoflagellate Oxyrrhis marina, and the scuticociliate Uronema sp.) and bacteria (Escherichia coli). This technique has the advantage, over the conventional CHN analysis of glass-fiber filters, of measuring total organic carbon in the liquid phase. Failing to retain small organisms on filters and cell rupture during filtration can thus be avoided. Cell volumes were measured on live (Coulter Counter) and Lugol's iodine- or formaldehyde-preserved cells and used to obtain a carbon:biovolume conversion factor for each spe-

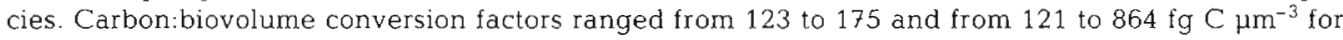
live and preserved cells, respectively. A linear regression of cell carbon content versus live biovolume gave a mean carbon:biovolume conversion factor of $125.3 \pm 7.6$ (SE) $\mathrm{fg}_{\mathrm{C}} \mu \mathrm{m}^{-3}$ for the 4 species studied with biovolumes ranging from 0.69 to $1590 \mu \mathrm{m}^{3}$ The data obtained in this study is compared to live and preserved cells data obtained from the literature and the possibility of using a single carbon:biovolume conversion factor for bacteria and protozoa is discussed.
\end{abstract}

KEY WORDS: Carbon content $\cdot$ Bacteria $\cdot$ Protozoa $\cdot$ Biovolume $\cdot$ Conversion factor

\section{INTRODUCTION}

Estimating the biomass of microorganisms is essential to evaluating their role in food webs and material cycling. Carbon biomass is usually estimated from population biovolumes (cell count multiplied by average cell biovolume) by using carbon:biovolume conversion factors. A wide range of carbon:biovolume conversion factors have been published for each microbial assemblage, ranging over 3 orders of magnitude (see 'Discussion'). These differences could be attributed to species-specific carbon:biovolume ratios, nutritional state of the organisms and the methodology employed. A number of studies have reported that preserved cell volumes are significantly different from live cell volumes (Børsheim \& Bratbak 1987, Choi \& Stoecker 1989, Verity et al. 1992). Most of the data on carbon content of microorganisms reported in the liter-

·E-mail: pelegri@ccrv.obs-vlfr.fr ature has been obtained by concentrating the organisms on pre-combusted Whatman GF/F filters which are subsequently burned on a CHN analyser (e.g. Bratbak 1985, Lee \& Fuhrman 1987). Few studies have used X-ray analysis of single cells in the scanning electron microscope (Norland et al. 1987), HPLC of hydrolysed amino acids (Simon \& Azam 1989) or radiolabelling techniques (Putt \& Stoecker 1989).

We present here a new method of measuring carbon content of microorganisms by high temperature catalytic oxidation (HTCO). This method has the advantage of measuring carbon content directly on liquid samples. Collecting the microorganisms on filters is not required, thus the risks involved in this manipulation are reduced (e.g. filter blank subtraction, cell destruction and loss). Cell rupture may result in underestimation of the microbial biomass because cell residues and soluble pools can pass through the filters (Nagata \& Kirchman 1990). In addition, it is very difficult to retain efficiently the smallest organisms on filters. For example, Whatman GF/F filters have a nominal retention 
size of $0.7 \mu \mathrm{m}$. Consequently, they cannot collect a significant fraction of the bacterial cells (Lee \& Fuhrman 1987, Lee 1993).

We used the HTCO technique to measure the carbon content of the helioflagellate Pteridomonas danica Patterson \& Fenchel (1985), the dinoflagellate Oxyrrhis marina Dujardin, the scuticociliate Uronema sp., and the enterobacteria Escherichia coli HB10B. Although we found in the literature a number of references on carbon:biovolume conversion factors for bacteria (e.g. Norland et al. 1995, Fagerbakke et al. 1996, Troussellier et al. 1997), only few studies have been conducted on protozoa (Børsheim \& Bratbak 1987, Putt \& Stoecker 1989, Ohman \& Snyder 1991). Carbon:biovolume conversion factors for protozoa have often been based on empirical equations developed for similarly sized microalgae or on theoretical assumptions about their specific gravity, dry weight content, and carbon content in dry weight (Beers \& Stewart 1970, Smetacek 1981, Fenchel \& Finlay 1983).

\section{MATERIAL AND METHODS}

We used for our experiments monospecific laboratory cultures of protozoa and bacteria.

Establishment of cultures. (1) Escherichia coli HB10B was grown on Luria-Bertani medium at $37^{\circ} \mathrm{C}$ and with vigorous shaking. The culture, which had reached -1 unit optical density at $600 \mathrm{~nm}$, was centrifuged (Centrikon T-124) at $9000 \mathrm{rpm}$ during $10 \mathrm{~min}$. The supernatant was substituted by filtered (consecutively Whatman GF/F, $0.8 \mu \mathrm{m}$ and $0.22 \mu \mathrm{m}$ Millipore filter units) and autoclaved seawater. Each centrifuge tube was sonicated for $1 \mathrm{~min}$ and centrifuged again. This procedure was repeated 5 times. This bacterial suspension, containing 2 to $3 \times 10^{9}$ cells $\mathrm{ml}^{-1}$, was then diluted and used in our experiments.

Escherichia coli was added to filtered and autoclaved seawater to a final concentration of $17.4 \pm 1.1 \times$ $10^{6}$ cells $\mathrm{ml}^{-1}$. This culture was then diluted with filtered and autoclaved seawater from 0 to 10 times in duplicate samples $(n=22)$. Ten $\mathrm{ml}$ of each sample was collected in $20 \mathrm{ml}$ ignited (at $500^{\circ} \mathrm{C}$ for $4 \mathrm{~h}$ ) Pyrex glass tubes, acidified to $\mathrm{pH}<2$ with $2 \mathrm{~N} \mathrm{HCl}$ and stored at $5^{\circ} \mathrm{C}$ until HTCO analysis.

(2) Oxyrrhis marina was fed Isochrysis galbana (CCMP1323). When the culture had reached the exponential growth phase, one half of it was filtered through $5 \mu \mathrm{m}$ pore-size Nuclepore polycarbonate filters and the filtrate used to dilute the other half of the culture from 0 to 10 times in duplicate $(n=22)$. The purpose of using the filtrate for diluting the original culture was to ensure that the background was equal, corresponding to I. galbana and seawater, in all sam- ples irrespective of their concentration of $O$. marina. Ten $\mathrm{ml}$ of each sample was collected in $20 \mathrm{ml}$ ignited Pyrex glass tubes and treated as described for Escherichia coli. The exponential growth phase culture contained $3.1 \pm 0.1 \times 10^{3}$ O. marina and $668 \mathrm{I}$. galbana $\mathrm{ml}^{-1}$. Cells of $O$. marina were not detected in the filtrate. The number of $I$. galbana in the original culture did not differ significantly $(p>0.5)$ from that in the filtrate.

(3) Uronema sp. was fed Escherichia coli. When the culture had reached the exponential growth phase, we enumerated the $E$. coli left. The culture was then diluted from 0 to 10 times in duplicate $(n=22)$ with filtered and autoclaved seawater containing an equal number of $E$. coli. Ten $\mathrm{ml}$ from each of these samples was collected in $20 \mathrm{ml}$ ignited Pyrex glass tubes and treated as described for $E$. coli. The exponential growth phase culture contained $1.7 \pm 0.0 \times 10^{3}$ Uronema sp. and $1.9 \times 10^{6} \mathrm{E}$. coli $\mathrm{ml}^{-1}$.

(4) Pteridomonas danica was fed natural bacteria isolated from Villefranche Bay. When the culture had reached the exponential growth phase, we enumerated the bacteria left. The culture was then diluted from 0 to 10 times in duplicate $(n=22)$ with filtered and autoclaved seawater containing an equal number of bacteria. Ten $\mathrm{ml}$ from each of these samples was collected in $20 \mathrm{ml}$ ignited Pyrex glass tubes and treated as for Escherichia coli. The original culture contained $1.0 \pm 0.1 \times 10^{5} \mathrm{P}$. danica and $1.1 \times 10^{7}$ bacteria $\mathrm{ml}^{-1}$.

Cell number determination. Cell number was determined with an electronic particle sizer on live samples (see below), and microscopically on formaldehyde- or Lugol's iodine-preserved samples.

Buffered formaldehyde-preserved samples $(2 \%$ final concentration vol./vol.) were stained with 4,6diamidino-2-phenylindole (DAPI, Sigma Chemical Co., $5 \mathrm{mg} \mathrm{l}^{-1}$ final concentration), filtered onto black $0.2 \mu \mathrm{m}$ pore-size Nuclepore polycarbonate filters (Porter \& Feig 1980), and examined under an epifluorescence Zeiss microscope. Escherichia coli was enumerated in quintuplicate at a magnification of $\times 2500$ and Pteridomonas danica in triplicate at a magnification of $\times 1250$. A total of 700 and 1500 cells were counted, respectively.

Lugol's iodine-fixed samples ( $2 \%$ final concentration vol./vol.) were counted on a Zeiss inverted microscope at a magnification of $\times 400$. A total of 2000 Oxyrrhis marina and Uronema sp. cells were counted in triplicate.

Biovolume determination. Biovolumes were measured with an electronic particle sizer on live samples, and microscopically on a minimum of 60 formaldehyde- or Lugol's iodine-preserved cells. In addition, unfixed DAPI-stained Escherichia coli were measured microscopically on a minimum of 60 cells. 
Live cell volumes were measured with the Coulter Counter for all species. The Coulter Counter may give imperfect measures of live cell volume when cells are nonspherical (Harbison \& McAlister 1980, Nilsson 1990, Montagnes et al. 1994). However, if a sufficiently high number of particles is counted to ensure an averaging of orientations of particles traversing the aperture, an accurate estimate of cell volume can be obtained. For this study, we measured a minimum of 16000 cells (Table 1) with a Coulter Counter (Multisizer) analysing system equipped with either a $20 \mu \mathrm{m}$ (for Escherichia coli and Pteridomonas danica) or $100 \mu \mathrm{m}$ (for Oxyrrhis marina and Uronema sp.) aperture tube. The Coulter Counter was calibrated with 2.09 and $19.32 \mu \mathrm{m}$ latex microspheres, respectively.

The biovolume of Escherichia coli was determined microscopically $(\times 2500)$ on DAPI-stained samples (as described in the preceding subsection). This determination was conducted on both live and formaldehydepreserved samples. Width (W) and length (L) were measured with a calibrated ocular micrometer. The shape of the cells was approximated to a cylinder with a hemisphere at each end (Bratbak 1985) and biovolumes were calculated as $\pi / 4 \times(\mathrm{L}-\mathrm{W} / 3) \times \mathrm{W}^{2}$.

The biovolume of Pteridomonas danica was determined on formaldehyde-preserved samples. Immediately, and 1 and $48 \mathrm{~h}$ after formaldehyde addition, $P$. danica's diameter was determined microscopically $(\times 1250)$ on DAPI-stained samples (as described in the preceding subsection). Cell biovolume was calculated as for a sphere, corresponding to the geometry of $P$. danica.

Biovolumes of Oxyrihis marina and Uronema sp. were determined on Lugol's iodine-preserved samples. One hour after Lugol's iodine addition, cell width (W) and length (L) were measured on a Zeiss inverted microscope $(\times 400)$. Biovolume was determined as for Escherichia coli.

Cell carbon determination. Total organic carbon was determined on $10 \mathrm{ml}$ samples by high temperature catalytic oxidation (HTCO) (e.g. Sharp et al. 1995). Samples were sparged with an artificial air mixture (AGA, France) (containing $\leq 0.1 \mathrm{ppm} \mathrm{CO}, \mathrm{CO}_{2}$ or hydrocarbons) in order to eliminate inorganic carbon, and measured on a Shimadzu TOC-5000 instrument equipped with a high sensitivity catalyst. Total organic carbon concentrations were calculated with the instru. ment software and a 4-point standard calibration curve made with potassium biphthalate. The coefficient of variation of triplicate injections was always $<2 \%$.

A linear regression analysis $(y=a x+b)$ was used to describe the relationship between the number of organisms $(x)$ and the corresponding concentration of carbon $(y)$ for each species. The slope of these linear regressions (a) is the carbon content per cell, and the intercept $(b)$ is the background carbon corresponding to seawater and prey items. A carbon:biovolume conversion factor was calculated for each species by diving carbon content per cell by mean cell biovolume.

Table 1. Size $(\mathrm{L}=$ length, $\mathrm{W}=$ width, $\mu \mathrm{m} \pm \mathrm{SD})$, biovolume $\left(\mu \mathrm{m}^{3} \pm \mathrm{SD}\right)$, carbon content per organism $\left(\mathrm{g} \mathrm{C}\right.$ org. $\left.{ }^{-1}\right)$, and calculated

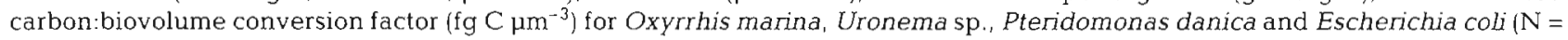
number of organisms studied). Cell size was determined on live cells (Coulter Counter) and on preserved cells (Lugol's iodine or formaldehyde (Form.), $2 \%$ final concentration vol./vol.)

\begin{tabular}{|c|c|c|c|c|c|c|c|c|}
\hline Organism & Method & & $\begin{array}{l}\text { Size } \\
(\mu \mathrm{m})\end{array}$ & $\begin{array}{l}\text { Volume } \\
\left(\mu \mathrm{m}^{3}\right)\end{array}$ & N & $\begin{array}{c}\text { Carbon } \\
\left(\text { g } C \text { org }^{-1}\right)\end{array}$ & $\mathrm{N}$ & $\begin{array}{l}\text { Carbon biovolume } \\
\qquad\left(\mathrm{fg} C \mu \mathrm{m}^{-3}\right)\end{array}$ \\
\hline \multirow[t]{2}{*}{ Oxyrrhis marina } & Coulter & & & $1590 \pm 860$ & 25018 & $196 \times 10^{-12}$ & 22 & 123 \\
\hline & Lugol & $\begin{array}{r}\mathrm{L} \\
W\end{array}$ & $\begin{array}{l}18.8 \pm 4.6 \\
12.4 \pm 1.9\end{array}$ & $1619 \pm 780$ & 64 & & & 121 \\
\hline \multirow[t]{2}{*}{ Uronema sp. } & Coulter & & & $846 \pm 157$ & 22850 & $121 \times 10^{-12}$ & 22 & 143 \\
\hline & Lugol & $\begin{array}{l}\mathrm{L} \\
\mathrm{W}\end{array}$ & $\begin{array}{r}18.5 \pm 2.3 \\
8.6 \pm 1.2\end{array}$ & $727 \pm 221$ & 64 & & & 166 \\
\hline \multirow[t]{2}{*}{ Pteridomonas danica } & Coulter & & $4.2 \pm 0.8$ & $39 \pm 30$ & 16430 & $52 \times 10^{-13}$ & 22 & 124 \\
\hline & $\begin{array}{r}\text { Form. } 0 \mathrm{~h}^{\mathrm{a}} \\
48 \mathrm{~h}\end{array}$ & & $\begin{array}{l}3.9 \pm 0.4 \\
3.4 \pm 0.3\end{array}$ & $\begin{array}{l}32 \pm 9 \\
21 \pm 5\end{array}$ & $\begin{array}{l}64 \\
64\end{array}$ & & & $\begin{array}{l}163 \\
248\end{array}$ \\
\hline \multirow[t]{3}{*}{ Escherichia coli } & Coulter & & & $0.69 \pm 0.3$ & 584554 & $121 \times 10^{-15}$ & 22 & 175 \\
\hline & DAPI $^{\mathrm{b}}$ & & $\begin{array}{l}2.1 \pm 0.6 \\
0.6 \pm 0.04\end{array}$ & $0.53 \pm 0.2$ & 70 & & & 228 \\
\hline & Formaldehyde & & $\begin{array}{l}0.9 \pm 0.3 \\
0.5 \pm 0.05\end{array}$ & $0.14 \pm 0.1$ & 64 & & & 864 \\
\hline
\end{tabular}




\section{RESULTS}

Figs. 1 to 4 show the relationship between cell number and carbon concentration for the 4 species studied. A significant linear relationship ( $p<0.0001$ ) was found between both parameters in all of them. The slope of the regression line represents the carbon content per cell and the intercept represents the background level, corresponding to prey items and seawater.

Table 1 shows the parameters involved in the calculation of the carbon:biovolume conversion factors for the 4 species. Carbon:biovolume conversion factors are calculated for live and preserved cells. The large standard deviations of biovolumes of all 4 species were

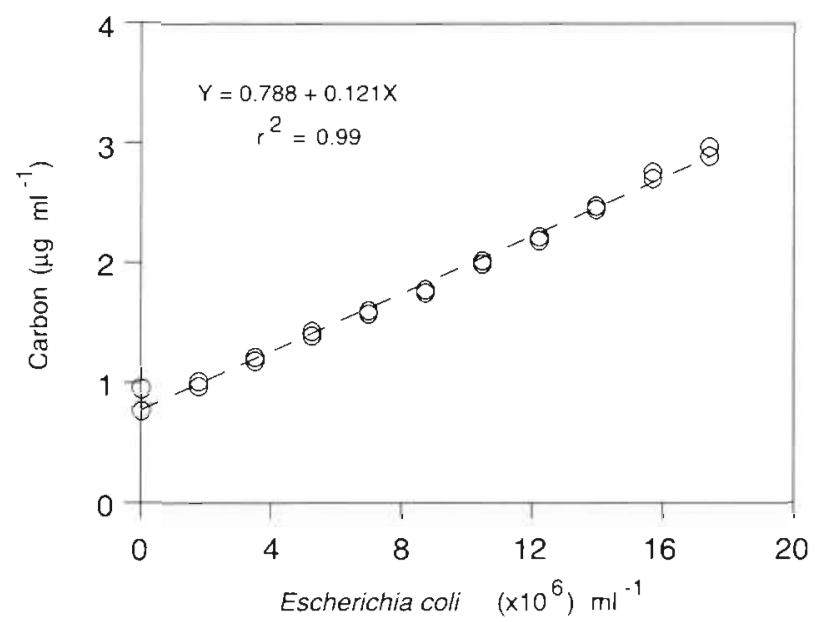

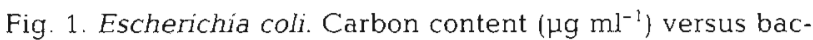
terial numbers $\left(\times 10^{6}\right) \mathrm{E}$. coli ml $\mathrm{m}^{-1}$. The slope of the regression line indicates the carbon content per cell, $121 \times 10^{-15} \mathrm{~g} \mathrm{C}$ E. coli $^{-1}$

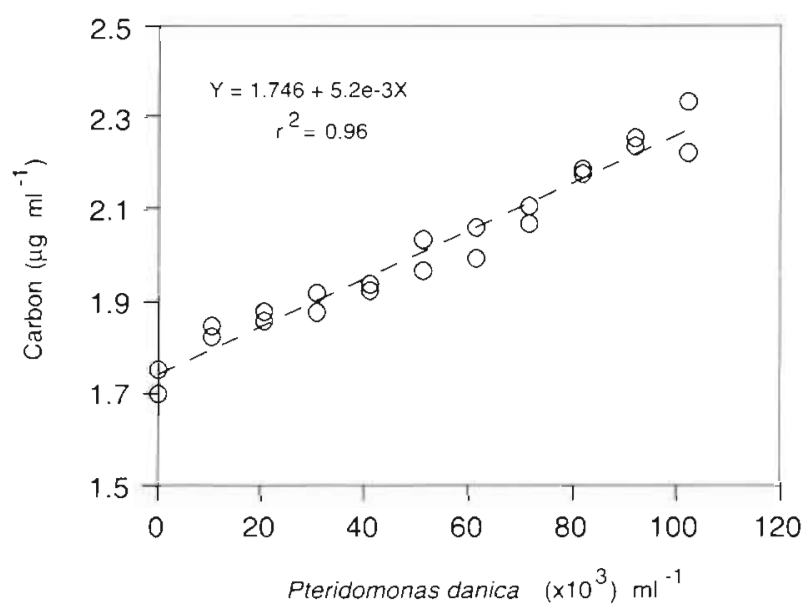

Fig. 2. Pteridomonas danica. Carbon content $\left(\mu \mathrm{g} \mathrm{ml}^{-1}\right.$ ) versus flagellate numbers $\left(\times 10^{3}\right) P$ danica $\mathrm{ml}^{-1}$. The slope of the regression line indicates the carbon content per cell, $52 \times$ $10^{-13} \mathrm{~g} \mathrm{C} \mathrm{P.} \mathrm{danica-1}$ attributed to growth-related size variations within the population.

We found no significant ( $p>0.3$ ) differences between live (Coulter Counter) and preserved Oxyrrhis marina cell volume. However, that was not the case for Uronema sp., Escherichia coli and Pteridomonas danica.

Uronema sp. volume decreased by fixation from $846 \pm$

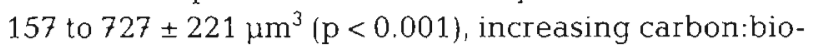

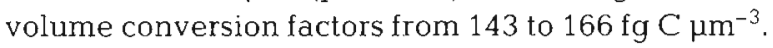

Escherichia coli decreased in volume from $0.69 \pm 0.3$ (live, Coulter Counter) to $0.53 \pm 0.2 \mu^{3}$ (23\%) after DAPI staining $(\mathrm{p}<0.001)$. Biovolume decreases were even more important when formaldehyde-preserved

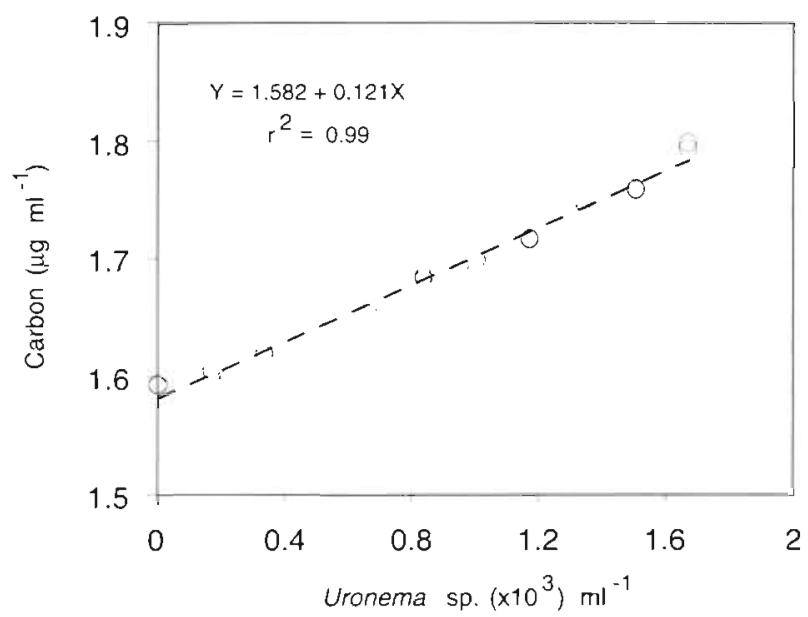

Fig. 3. Uronema sp. Carbon content $\left(\mu \mathrm{g} \mathrm{m} \mathrm{m}^{-1}\right)$ versus ciliate numbers $\left(\times 10^{3}\right)$ Uronema $\mathrm{ml}^{-1}$ The slope of the regression line indicates the carbon content per cell, $121 \times 10^{-12} \mathrm{~g} \mathrm{C}$ Uronema-

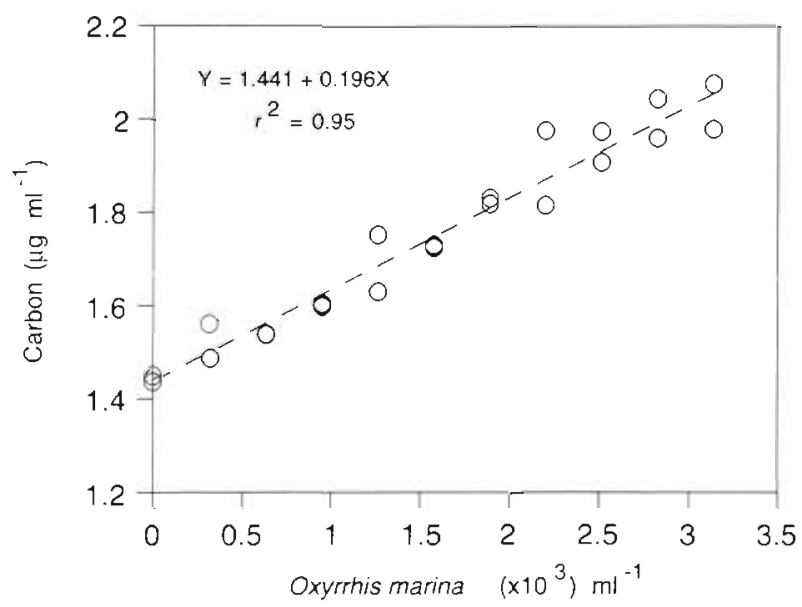

Fig. 4. Oxyrrhis marina. Carbon content $\left(\mu \mathrm{g} \mathrm{m} \mathrm{m}^{-1}\right)$ versus flagellate numbers $\left(\times 10^{3}\right) \quad 0$. marina $\mathrm{ml}^{-1}$ The slope of the regression line indicates the carbon content per cell, $196 \times$ $10^{-12} \mathrm{~g} \mathrm{C} \mathrm{O.} \mathrm{marina}{ }^{-1}$ 
cells were DAPI stained, from $0.69 \pm 0.3$ to $0.14 \pm 0.1$ $\mu \mathrm{m}^{3}(80 \%)$. As a result of these changes in cell volume, the carbon:biovolume conversion factor increased from $175 \mathrm{fg} \mathrm{C} \mu \mathrm{m}^{-3}$ for live $E$. coli cells to 228 and $864 \mathrm{fg} \mathrm{C}$ $\mu^{-3}$ for DAPI-live and DAPI-preserved cells, respectively.

Pteridomonas danica volume decreased by fixation with formaldehyde. The initial volume of $39 \pm 30 \mu^{3}$ (live, Coulter Counter) was reduced to $32 \pm 9 \mu^{3}$ $(17 \%)$ just after fixation ( $\mathrm{p}<0.001)$, to $28 \pm 9 \mu^{3}$ ( $\mathrm{n}=$ 64) $(28 \%) 1 \mathrm{~h}$ after fixation and to $21 \pm 5 \mu^{3}(\mathrm{n}=64)$ (46\%) 48 h later (data not shown). Consequently, carbon:biovolume conversion factors increased from 124

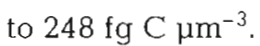

Taking into account only live biovolumes, we found a good correlation between biovolume $\left(x, \times 10^{3} \mu \mathrm{m}^{3}\right)$ and carbon content $\left(y, p g C\right.$ cell $^{-1}$ ) of all 4 species $(y=$ $\left.3.0+125.3 x, r^{2}=0.994, p<0.004\right)$, giving a mean conversion factor for bacteria and protozoa of $125.3 \pm 7.6$ (mean $\pm \mathrm{SE}$ ) fg $\mathrm{C} \mathrm{m}^{-3}$.

\section{DISCUSSION}

In this study, the HTCO technique was applied for the first time to the measurement of carbon content of microorganisms. By using this technique, we obtained a carbon:biovolume conversion factor of $125{\mathrm{fg} \mathrm{C} \mu \mathrm{m}^{-3}}^{-3}$ for organisms ranging in volume from 0.69 to 1590 $\mu^{3}$ : bacteria, nanoflagellates, dinoflagellates and ciliates. Below, we compare this carbon:biovolume conversion factor and each species-specific conversion factor to the values reported in the literature. In addition, we discuss the effect of cell preservation on cell volume and consequently on carbon:biovolume conversion factors.

Live Escherichia coli carbon:biovolume conversion

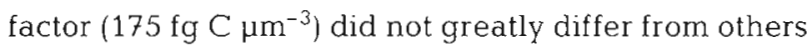
reported previously in the literature 190 to $170 \mathrm{fg} \mathrm{C}$

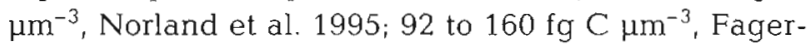
bakke et al. 1996). Live Uronema sp. carbon:biovolume

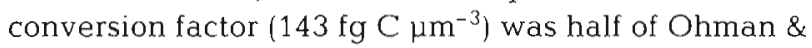
Snyder's (1991) conversion factor (323 fg C $\mu \mathrm{m}^{-3}$, $710 \mu^{3}$ ), while our carbon: biovolume conversion factor

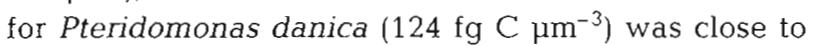
the only other reference found for live nanoflagellates (96.1 fg C $\mathrm{fm}^{-3}$ for Monas sp., Børsheim \& Bratbak 1987).

This study provides the first carbon:biovolume conversion factor for non-preserved heterotrophic dinofla-

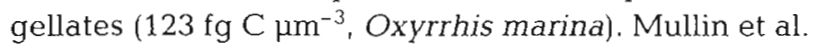
(1966) had measured a carbon:biovolume conversion

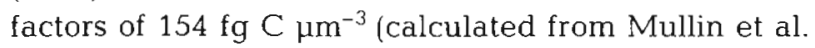
data) for the autotrophic dinoflagellate Peridinium trochoideum. In their study, cell biovolume was deter- mined on live cells (Coulter Counter) and cell carbon content was measured by wet oxidation.

Lugol's iodine preservation ( $2 \%$ final concentration vol./vol.) did not affect significantly live (Coulter Counter) cell volumes of Oxyrrhis marina. If there was any difference in volume between live and preserved cells, it was masked by the wide range of cell volumes of the population. However, a slight decrease in volume was observed in Uronema sp. Lugol's iodine-preserved cells. Various authors have reported Lugol's iodine ( 1 to $10 \%$ vol./vol.) underestimation of live protozoa and algae cell volumes (Choi \& Stoecker 1989 Putt \& Stoecker 1989, Montagnes et al. 1994).

Cell preservation with formaldehyde ( $2 \%$ final concentration vol./vol.) did decrease Pteridomonas danica live volume by 17,28 and $46 \%$ immediately, $1 \mathrm{~h}$ and $48 \mathrm{~h}$ after fixation, respectively. Formaldehyde has been reported to underestimate (Børsheim \& Bratbak 1987) but also to overestimate (Putt \& Stoecker 1989) live cell volumes of protozoa. Borsheim \& Bratbak (1987) reported the nanoflagellate Monas sp. cell volume to decrease by 27 and $53 \% 2 \mathrm{~h}$ and $2 \mathrm{wk}$ after formaldehyde $(5 \%$ final concentration) addition, respectively.

DAPI staining live Escherichia coli resulted in lower cell volumes by $23 \%$, while DAPI staining of formaldehyde-preserved bacteria resulted in lower cell volumes by $80 \%$. DAPI is not entirely specific for DNA (Mostajir et al. 1995) and has been reported to have a halo effect which may lead to inaccurate microscopically determined cell sizes (Schumann \& Rentsch 1998). Fixatives have been reported to cause a significant cell volume reduction in bacteria (Trueba \& Woldringh 1980, Fuhrman 1981, Kogure \& Koike 1987, Fagerbakke et al. 1996), although no significant effect was observed of formaldehyde addition $(0.2 \%)$ by Fry \& Davies (1985).

Our data indicates that preservation with Lugol's iodine or formaldehyde leads to cell shrinkage. Cell volume reduction was more important for smaller compared to larger organisms. For the former organisms, cell preservation led to overestimated carbon:biovolume conversion factors. We compared previously reported preserved and live cell means of carbon:biovolume conversion factors calculated for bacteria, $517 \pm 423$ versus $90 \pm 40 \mathrm{fgC}_{\mathrm{Cm}}^{-3}$, and concluded that preservation leads to higher carbon:biovolume conversion factors $(p<0.001)$ (Table 2$)$. In these studies, preservation was conducted with glutaraldehyde $(0.5-25 \%)$, formaldehyde $(2-4 \%)$ and Lugol's iodine $(2 \%)$. Not enough data was available for testing the effect of preservation on carbon:biovolume conversion factors for small flagellates and ciliates. However, both mean literature conversion factors and changes in factors due to preservation-related shifts in cell volumes are in agreement with our results. 
Table 2. Carbon:biovolume conversion factors ( $\mathrm{fg} \mathrm{C} \mu \mathrm{m}^{-3}$ ) obtained from the literature. Conversion factors are given for bacteria, small flagellates, ciliates and ciliate tintinnida live and preserved cells (size range between parenthesis). $\mathrm{N}=$ number of data points. Only data plotted in Fig. 5 and thus including carbon content per cell and biovolume per cell are shown

\begin{tabular}{|c|c|c|c|c|c|c|}
\hline Organisms & Live & $N$ & Source & Preserved & $N$ & Source \\
\hline $\begin{array}{l}\text { Bacteria } \\
\left(0.076-4.2 \mu \mathrm{m}^{3}\right)\end{array}$ & $\begin{array}{l}90-170 \\
32-160\end{array}$ & $\begin{array}{r}2 \\
10\end{array}$ & $\begin{array}{l}\text { Norland et al. (1995) } \\
\text { Fagerbakke et al. (1996) }\end{array}$ & $\begin{array}{l}260-800 \\
106 \\
446 \\
381-1838 \\
210-1610 \\
461-692 \\
26-171\end{array}$ & $\begin{array}{r}6 \\
1 \\
1 \\
10 \\
7 \\
1 \\
10\end{array}$ & $\begin{array}{l}\text { Bratbak (1985) } \\
\text { Nagata (1986) } \\
\text { Børsheim \& Bratbak (1987) } \\
\text { Bjørnsen \& Kuparinen (1991) } \\
\text { Kroer (1994) } \\
\text { Zubkov \& Sleigh (1995) } \\
\text { Troussellier et al. (1997) }\end{array}$ \\
\hline $\begin{array}{l}\text { Small flagellates } \\
\left(7.8-212 \mu \mathrm{m}^{3}\right)\end{array}$ & 99 & 1 & Børsheim \& Bratbak (1987) & $\begin{array}{l}120-190 \\
220 \\
250-370 \\
63-198\end{array}$ & $\begin{array}{l}2 \\
1 \\
4 \\
1\end{array}$ & $\begin{array}{l}\text { Fenchel (1982) } \\
\text { Børsheim \& Bratbak (1987) } \\
\text { Geider \& Leadbeater (1988) } \\
\text { Nakano (1994) }\end{array}$ \\
\hline $\begin{array}{l}\text { Ciliates } \\
\left(710-76300 \mu \mathrm{m}^{3}\right)\end{array}$ & $\begin{array}{c}148 \\
126-323\end{array}$ & $\begin{array}{l}1 \\
3\end{array}$ & $\begin{array}{l}\text { Putt \& Stoecker }(1989)^{d} \\
\text { Ohman \& Snyder (1991) }\end{array}$ & $140-190$ & 2 & Putt \& Stoecker (1989) \\
\hline $\begin{array}{l}\text { Ciliate tintinnida } \\
\left(9198-3.1 \times 10^{5} \mathrm{~mm}^{3}\right)\end{array}$ & - & - & - & $\begin{array}{c}88 \\
45-87 \\
60-74\end{array}$ & $\begin{array}{l}1 \\
9 \\
1\end{array}$ & $\begin{array}{l}\text { Heinbokel (1978) } \\
\text { Verity \& Langdon (1984) } \\
\text { Zubkov \& Sleigh (1995) }\end{array}$ \\
\hline
\end{tabular}

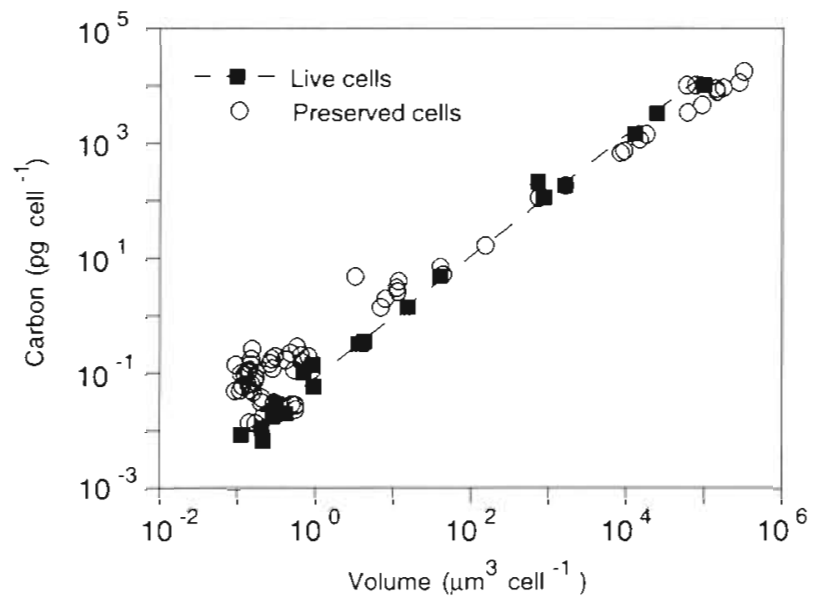

Fig. 5. Log-log cell carbon content (pg cell $\left.{ }^{-1}\right)$ versus volume $\left(\mu \mathrm{m}^{3} \mathrm{cell}^{-1}\right)$ for bacteria and protozoa. (0) Preserved samples $(\mathrm{n}=63)$; $(\mathbf{\square})$ live samples $(\mathrm{n}=21)$. Data obtained from this article and the literature (see Table 2 for references)

An allometric relation is apparrent in Fig. 5 between carbon content and volume per cell for all the data points $(n=84)$. A log-log representation was used to allow 8 orders of magnitude in cell carbon and volume to be plotted on a single graph. We analysed the data with linear regression techniques.

A good correlation was obtained for live cells: bacteria volume versus carbon content $\left[x=\log \left(\mu \mathrm{m}^{3}\right.\right.$ cell $\left.{ }^{-1}\right)$, $y=\log \left(\mathrm{pg} C \mathrm{cell}^{-1}\right), y=-1.036+1.153 x, \mathrm{r}^{2}=0.905, \mathrm{n}=$ $13, p<0.0001]$, bacteria and small flagellate volume versus carbon content $\left(y=-1.051+1.114 x, r^{2}=0.953\right.$, $\mathrm{n}=15, \mathrm{p}<0.0001)$, and volume of all organisms versus their carbon content $\left(y=-1.046+1.058 x, r^{2}=0.991, n=\right.$ $21, \mathrm{p}<0.0001)$. The slopes of the regression lines were not significantly different from unity $(p>0.3)$ indicating that there was a similar carbon content of the organisms as a function of volume. Carbon:biovolume

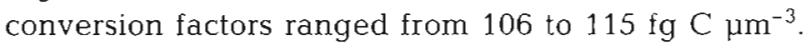
When plotting our live-cell experimental data on a loglog representation we obtained a carbon:biovolume

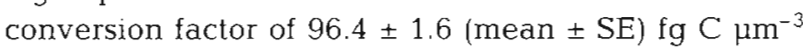
$\left[x=\log \left(\mu \mathrm{m}^{3} \mathrm{cell}^{-1}\right), y=\log \left(\mathrm{pg} \mathrm{C} \mathrm{cell}^{-1}\right), y=-0.778+\right.$ $\left.0.964 x, r^{2}=0.999, n=4, p<0.0004\right]$, which is close to the above calculated carbon:biovolume conversion factors.

A weaker correlation was observed for preserved organisms: bacteria volume versus carbon content $[x=$ $\log \left(\mu \mathrm{m}^{3} \mathrm{cell}^{-1}\right), y=\log \left(\mathrm{pg} \mathrm{C} \mathrm{cell}^{-1}\right), y=-0.912+0.274 x_{\text {, }}$ $\mathrm{r}^{2}=0.04, \mathrm{n}=38, \mathrm{p}>0.2 \mathrm{]}$, bacteria and small flagellate volume versus carbon content $\left(y=-0.485+0.874 x, \mathrm{r}^{2}=\right.$ $0.718, n=47, p<0.0001$ ), and volume of all organisms versus their carbon content $\left(y=-0.488+0.869 x, r^{2}=\right.$ $0.968, \mathrm{n}=63, \mathrm{p}<0.0001$ ). The slope of the regression line was significantly lower than unity $(p<0.002)$ for bacteria. Thus, according to these data smaller bacteria would have a higher carbon content than larger bacteria. Some authors reported that carbon:biovolume for bacteria changed from small to big bacteria, the former containing more carbon per unit of volume (Norland et al. 1987, Lee \& Fuhrman 1987, Simon \& Azam 1989), whereas such a trend was not found by others (Fagerbakke et al. 1996). The former studies were conducted on preserved cells but the latter on 
live cells. Thus, cell preservation may be the explanation for these observed differences and for the higher carbon:biovolume conversion factors reported by Bratbak (1985).

We conclude that high temperature catalytic oxidation (HTCO) can provide accurate carbon contents of microorganisms. HTCO presents the advantage over the conventional CHN analysis of directly measuring liquid samples; filtration can thus be avoided. Our study indicates that a single carbon:biovolume conver-

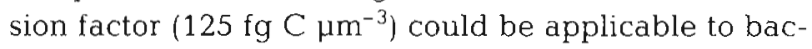
teria and protozoa. The high variability in carbon:biovolume conversion factors reported in the literature would result from different degrees of cell shrinkage by preservation rather than from species-specific physiologic or taxonomic differences. Shrinkage of cells after fixation, which may be variable depending on the species, should be taken into account when calculating microbial biomasses.

Acknowledgements. We thank Prof Tom Fenchel for identifying our nanoflagellate. The comments of Drs Serge Dallot, Christine Ferrier-Pagès, Jean-Pierre Gattuso and Toshi Nagata on the manuscript were very helpful. We also thank Drs Gérard Copin-Montégut and Bernard Avril for their help with the TOC analyser. We are grateful to Dr Benoit Dérijard for providing Escherichia coli $\mathrm{HB} 10 \mathrm{~B}$ and to Dr Philippe Huitorel for providing Oxyrrhis marina. This work was supported by the European Commission through MAS3-CT950016 ('Medea').

\section{LITERATURE CITED}

Beers JR, Stewart GL (1970) Numerical abundance and estimated biomass of microzooplankton. In: Strickland JDH (ed) The ecology of the plankton off La Jolla, California, in the period April through September, 1967. Bull Scripps Inst Oceanogr, San Diego, p 67-87

Bjørnsen PK, Kuparinen J (1991) Determination of bacterioplankton biomass, net production and growth efficiency in the Southern Ocean. Mar Ecol Prog Ser 71:185-194

Børsheim KY, Bratbak G (1987) Cell volume to cell carbon conversion factors for a bacterivorous Monas sp. enriched from seawater. Mar Ecol Prog Ser 36:171-175

Bratbak G (1985) Bacterial biovolume and biomass estimations. Appl Environ Microbiol 49:1488-1493

Choi JW, Stoecker DK (1989) Effects of fixation on cell volume of marine planktonic protozoa. Appl Environ Microbiol 55: $1761-1765$

Fagerbakke KM, Heldal M, Norland S (1996) Content of carbon, nitrogen, oxygen, sulfur and phosphorus in native aquatic and cultured bacteria. Aquat Microb Ecol 10: $15-27$

Fenchel T (1982) Ecology of heterotrophic microflagellates. II. Bioenergetics and growth. Mar Ecol Prog Ser 8:225-231

Fenchel T, Finlay BJ (1983) Respiration rates in heterotrophic free-living Protozoa. Microb Ecol 9:99-122

Fry JC, Davies AR (1985) An assessment of methods for measuring volumes of planktonic bacteria, with particular reference to television image analysis. J Appl Bact 58: $105-112$
Fuhrman JA (1981) Influence of method on the apparent size distribution of bacterioplankton cells: epifluorescence microscopy compared to scanning electron microscopy Mar Ecol Prog Ser 5:103-106

Geider RJ, Leadbeater BSC (1988) Kinetics and energetics of growth of the marine choanoflagellate Stephanoeca diplocostata. Mar Ecol Prog Ser 47:169-177

Harbison GR, MCAlister VL (1980) Fact and artifact in copepod feeding experiments. Limnol Oceanogr 25:971-981

Heinbokel JF (1978) Studies on the functional role of tintinnids in the Southern California Bight. 1. Grazing and growth rates in laboratory cultures. Mar Biol 47:177-189

Kogure K, Koike I (1987) Particle counter determination of bacterial biomass in seawater. Appl Environ Microbiol 53 $274-277$

Kroer $N$ (1994) Relationships between biovolume and carbon and nitrogen content of bacterioplankton. FEMS Microbiol Ecol 13:217-224

Lee S (1993) Measurement of carbon and nitrogen biomass and biovolume from naturally derived marine bacterioplankton. In: Kemp PF, Sherr BF, Sherr EB, Cole JJ (eds) Handbook of methods in aquatic microbial ecology. Lewis Publishers, Boca Raton, Fl, p 319-325

Lee S, Fuhrman JA (1987) Relationship between biovolume and biomass of naturally derived marine bacterioplankton. Appl Environ Microbiol 53:1298-1303

Montagnes DJS, Berges JA, Harrison PJ, Taylor FJR (1994) Estimating carbon, nitrogen, protein, and chlorophyll a from volume in marine phytoplankton. Limnol Oceanogr 39:1044-1060

Mostajir B, Dolan JR, Rassoulzadegan F (1995) A simple method for the quantification of a class of labile marine pico- and nano-sized detritus: DAPI yellow particles (DYP). Aquat Microb Ecol 9:259-266

Mullin MM. Sloan PR, Eppley RW (1966) Relationship between carbon content, cell volume, and area in phytoplankton. Limnol Oceanogr 11:307-311

Nagata $T$ (1986) Carbon and nitrogen content of natural planktonic bacteria. Appl Environ Microbiol 52:28-32

Nagata T, Kirchman DL (1990) Filtration-induced release of dissolved free amino acids: application to cultures of marine protozoa. Mar Ecol Prog Ser 68:1-5

Nakano SI (1994) Carbon:nitrogen:phosphorus ratios and nutrient regeneration of a heterotrophic flagellate fed on bacteria with different elemental ratios. Arch Hydrobiol $129: 257-271$

Nilsson JR (1990) On the correlation of the volume of a prolate-spheroidal cell. Tetrahymena, as determined by electronic particle counters and by morphometry. J Protozool $37.500-504$

Norland S, Fagerbakke KM, Heldal M (1995) Light element analysis of individual bacteria by $X$-ray microanalysis. Appl Environ Microbiol 61:1357-1362

Norland S, Heldal M, Tumyr O (1987) On the relation between dry matter and volume of bacteria. Microb Ecol 13:95-101

Ohman MD, Snyder RA (1991) Growth kinetics of the omnivorous oligotrich ciliate Strombidium sp. Limnol Oceanogr 36:922-935

Patterson DJ, Fenchel T (1985) Insights into the evolution of heliozoa (Protozoa, Sarcodina) as provided by ultrastructural studies on a new species of flagellate from the genus Pteridomonas. Biol J Linn Soc 34:381-403

Porter KG, Feig YS (1980) The use of DAPI for identifying and counting aquatic microflora. Limnol Oceanogr 25:943-948

Putt M. Stoecker DK (1989) An experimentally determined carbon:volume ratio for marine 'oligotrichous' ciliates from 
estuarine and coastal waters. Limnol Oceanogr 34: $1097-1103$

Simon M, Azam F (1989) Protein content and protein synthesis rates of planktonic marine bacteria. Mar Ecol Prog Ser 51:201-213

Schumann R, Rentsch D (1998) Staining particulate organic matter with DTAF - a fluorescence dye for carbohydrates and protein: a new approach and application of a 2D image analysis system. Mar Ecol Prog Ser 163:77-88

Sharp JH, Benner R, Bennett L, Carlson CA, Fitzwater SE, Peltzer ET, Tupas LM (1995) Analyses of dissolved organic carbon in seawater: the JGOFS EqPac methods comparison. Mar Chem 48:91-108

Smetacek V (1981) The annual cycle of the protozooplankton in Kiel Bight. Mar Biol 63:1-11

Troussellier M, Bouvy M, Courties C, Dupuy C (1997) Varia-

Editonal responsibility: Tom Fenchel,

Helsingor, Denmark tion of carbon content among bacterial species under starvation condition. Aquat Microb Ecol 13:113-119

Trueba FJ, Woldringh CL (1980) Changes in cell diameter during division cycle of Escherichia coli. J Bacteriol 142: 869

Verity PG, Robertson CY, Tronzo CR, Andrews MG, Nelson JR, Sieracki ME (1992) Relationships between cell volume and the carbon and nitrogen content of marine photosynthetic nanoplankton. Limnol Oceanogr 37:1434-1446

Verity PG, Langdon C (1984) Relationships between lorica volume, carbon, nitrogen, and ATP content of tintinnids in Narragansett Bay. J Plankton Res 6:859-868

Zubkov MV, Sleigh MA (1995) Bacterivory by starved marine heterotrophic nanoflagellates of two species which feed differently, estimated by uptake of dual radioactivelabelled bacteria. FEMS Microbiol Ecol 17:57-66

Submitted: May 9, 1998; Accepted: July 15, 1998 Proofs received from author(s): January 20, 1999 